\title{
Comparative performance of forage cluster bean accessions as companion crops with sorghum under varied harvesting times
}

\author{
Muhammad Aamir lqbal \\ University of Poonch Rawalakot - Department of Agronomy - Rawalakot, Pakistan.
}

\begin{abstract}
Harvesting time and type of accession of forage legumes are important factors to determine their performance as companion crops for cereals. The objective of this multi-year field trial was to evaluate different harvesting times of forage cluster bean accessions sown as companion crops with forage sorghum under irrigated conditions. Treatments included two accessions (BR-90 and BR-99) and four harvesting times (pre-flowering, complete flowering, 50 and $100 \%$ pod formation). The BR-99 accession harvested at $100 \%$ pod formation had greater performance with respect to green forage yield (20.42 $\left.\mathrm{t} \cdot \mathrm{ha} \mathrm{a}^{-1}\right)$ and dry matter biomass $\left(5.80 \mathrm{t} \cdot \mathrm{ha}^{-1}\right)$ and it was statistically at par within the same accession harvested at $50 \%$ pod
\end{abstract}

formation. The highest quality forage with the maximum crude protein and ether extractable fat and lowest crude fiber was recorded by BR-99 harvested at $50 \%$ pod formation, while BR-90 did not perform at par at all harvesting times. Harvesting of BR-99 at $100 \%$ pod formation also resulted in the highest net income along with the benefit-cost ratio. The harvesting of BR-99 at 50 and $100 \%$ pod formation resulted in non-significant differences of forage yields and economic returns, however, the quality of cluster bean forage deteriorated at $100 \%$ pod formation thus harvesting at 50\% pod formation would be preferred. Key words: Animal nutrition, Cyamopsis tetragonoloba Taub, forage legumes, strip-intercropping, Sorghum bicolor L. 


\section{INTRODUCTION}

Mixed forage of cereal-legumes intercropping systems is an indispensable component of animal feed due to better agro-qualitative attributes, especially protein. Forage crops exhibit different growth patterns, yield and agro-qualitative attributes in intercropping than in pure stands (Iqbal et al. 2018a). Intercropping of two or more forage species is characterized by competition for applied growth resources including moisture and nutrients (Iqbal et al. 2015). The degree of competition and its impact on productivity of companion crops must be determined in varied cereal-legume intercropping systems (Ahmad et al. 2007; Allen et al. 2007). Cluster bean (Cyamopsis tetragonoloba Taub.) is a towering or spreading type bushy summer season leguminous crop that has deep roots, low transpiration rates and is suited to be intercropped with cereal forages (Ayub et al. 2012; Ayub and Shoaib 2009). It can meet a greater part of its nitrogen requirement from biological nitrogen fixation (Ayub et al. 2011; Zerbini and Thomas 2003). Cluster bean has also been reported to supply small amounts of fixed nitrogen to companion crops through the intermingling of roots (Ayub et al. 2010). It can produce substantial biomass, even on marginal soils characterized by suboptimal fertility. It is considered to be a favorite choice for farmers in moisture deficient and drought prone areas, in semi-arid to arid regions of the world (Iqbal 2015). It has the potential to supply nutritious forage to ruminants during summer months, but its biomass production is not comparable to that of cereal forages, like sorghum. Therefore, cluster bean is often intercropped with sorghum to increase the productivity per unit land area and the agro-qualitative attributes of mixed forages (Iqbal and Iqbal 2015; Ghosh et al. 2009; Ghanbari and Lee 2003).

In intercropping systems, sorghum has been found to be the dominant crop (Lesoing and Francis 1999) and more competitive for applied farm resources than cluster bean. Furthermore, shading by sorghum affects the morphological development and forage quality of cluster bean when intercropped with sorghum (Iqbal et al. 2017). Thus, considering the competitive effects, the harvesting time could affect the forage yield of cluster bean, including its protein content. Furthermore, the loss in biomass production and quality deterioration of forage cluster bean in intercropping with sorghum may be eliminated, or at least diminished, by adjusting its harvesting time as a variety of morphological, physiological and biochemical changes occur at different growth stages.
To date, no systematic research has been conducted to determine the effect on forage yields and quality under cluster bean and sorghum intercropping. We hypothesized that harvesting time affects forage yield, agro-qualitative attributes and economic returns of different cluster bean accessions. Thus, this field study attempted to determine the most appropriate harvesting time of different accessions of cluster bean grown as intercrops with sorghum, under irrigated conditions for higher biomass along with improved agro-qualitative attributes and monetary benefits.

\section{MATERIALS AND METHODS}

This field study was conducted during 2015 and repeated during 2016 under the same conditions, but at different locations on the Agronomic Research Farms of the University of Agriculture Faisalabad, Pakistan $\left(30.35-31.47^{\circ} \mathrm{N}\right.$ and 72.08-73. $0^{\circ} \mathrm{E}$ and alt. of $184 \mathrm{~m}$ ). Koppen-Geiger classification categorizes the climate of Faisalabad as semi-arid, while its soil is Haplic Yermosols as per FAO's classification scheme (Iqbal et al. 2018b). Composite samples of experimental soil were prepared by thoroughly mixing integral samples collected from 15 and $30 \mathrm{~cm}$ depth to determine the physico-chemical properties. The textural class of the experimental soil was sandy clay loam and was deficient in nitrogen and phosphorous, while the organic matter percentage was only $0.8 \%$. The $\mathrm{pH}$ of the soil was between 7.6 and 7.8 during both years. The mean daily temperature was 34 to $46^{\circ} \mathrm{C}$ during the crop growing season (late May to early August), while total precipitation was $140 \mathrm{~mm}$ as per an agro-meteorological observatory, located at a distance of about $1 \mathrm{~km}$ from the experimental site.

The experimental treatments included two accessions of cluster bean (BR-90 and BR-99) having an upright growth, single stem, glabrous leaves with tap root system (Alshameri et al. 2017) and four harvesting times (pre-flowering, complete flowering, 50\% pod formation and $100 \%$ pod formation). A randomized complete block design (RCBD) in factorial arrangement was employed, with three replications per treatment. Cluster bean and sorghum were sown in 5 row strips while the line to line and strip to strip spacing was maintained at $30 \mathrm{~cm}$. The (net) plot size was $3.2 \times 15 \mathrm{~m}$ with sixteen rows in each plot.

Seed bed preparation was stared with a pre-sowing irrigation of $12 \mathrm{~cm}$ and, when the soil reached an appropriate moisture level, three cultivations with a tractor mounted 
cultivator were carried out. Every cultivation was followed by light planking to prepare a fine seed bed. Cluster bean (BR-99 and BR-90) was sown as an intercrop with forage sorghum, using a seeding rate of $40 \mathrm{~kg} \cdot \mathrm{ha}^{-1}$, while the seed rate of forage sorghum was $85 \mathrm{~kg} \cdot \mathrm{ha}^{-1}$. The sowing of component crops was accomplished using a single row hand (cotton) drill. Plant to plant distance was given no consideration. Full dose of recommended phosphorous (40 kg.ha-1 elemental P) as single super phosphate $\left[\mathrm{Ca}\left(\mathrm{H}_{2} \mathrm{PO}_{4}\right)_{2}+\mathrm{CaSO}_{4}\right]$ was applied at the time of sowing, while nitrogen as urea $\left[\left(\mathrm{NH}_{2}\right)_{2} \mathrm{CO}\right]\left(60 \mathrm{~kg} \cdot \mathrm{ha}^{-1}\right.$ elemental $\left.\mathrm{N}\right)$ was applied in two splits (first as a basal dose and then applied with first irrigation at 16 days after sowing). Proper moisture conditions were maintained in order to prevent the onset of drought conditions by applying three flood irrigations of $7.5 \mathrm{~cm}$ each at 16, 35 and 48 days after sowing. Cluster bean was harvested as per treatment, with the help of hand sickles.

Data regarding experimental variables like plant height, stem girth, leaf number per plant, etc. were recorded using ten randomly selected plants from every experimental unit of each replication. Their average was then used to statistically analyze and interpret recorded data. Plant height of cluster bean was recorded from base to tip of harvested plants with a tailor's measuring tape and then averaged. Stem girth of cluster bean was recorded from three points, including base, mid and top, with the help of a vernier caliper and then their average was determined for statistical analysis. Crude protein, crude fiber, ether extractable fat and total ash of cluster bean were determined using standard techniques, as described in Table 1.

A partial budgeting technique for the companion crops was employed in order to determine the economic feasibility of cluster bean based intercropping systems. The benefit to cost ratio (BCR) which depicts monetary benefits for each additional unit of expenditures was calculated using Eq. 1:
$\mathrm{BCR}=\frac{\text { Gross monetary benefits }}{\text { Sum total of all expenditures }}$

(fixed + variable)

Gross monetary benefits (GMB) were calculated by using Eq. 2:

$\mathrm{GMB}=\begin{gathered}\text { Total economic } \\ \text { yield }\end{gathered} \times \begin{gathered}\text { Market rate per unit of } \\ \text { economic yield }\end{gathered}$

Net monetary benefits (NMB), which depict the actual economic returns that the farmers receive for their investment and labor was calculated with Eq. 3 as described in CIMMYT (1988);

$\mathrm{NMB}=\mathrm{GMF}-\quad$ Sum total of all expenditures

$$
\text { (fixed + variable) }
$$

where gross monetary benefit (GMB) is the same as that of Eq. 2 and total expenditures are the same as for Eq. 1.

For statistical analysis, an analysis of variance (ANOVA) technique was employed using the statistical program SAS 9.5 (SAS Institute, USA), while Duncan's multiple range test was employed to separate treatment means. Correlation analysis was also performed to determine and establish the relationship between yield components and green forage yield of cluster bean.

\section{RESULTS AND DISCUSSION Green forage yield and dry matter yield $\left(t \cdot h a^{-1}\right)$}

It is important to monitor and boost forage yield to increase the productivity of cluster bean based intercropping systems. The interaction between accession $(\mathrm{p} \leq 0.01)$ and harvesting time $(\mathrm{p} \leq 0.05)$ was significant for green forage yield and dry matter biomass (Table 2). Harvesting at the 100\%

Table 1. Procedure followed to determine crude protein, crude fiber, ether extractable fat and total ash of forage cluster bean accessions (BR-99 and BR-90) grown as companion crops with sorghum at different harvesting times (pre-flowering, complete flowering, $50 \%$ and $100 \%$ pod formation) under irrigated conditions at Faisalabad, Pakistan during 2015 and 2016.

\begin{tabular}{|c|c|c|}
\hline Quality attributes & Technique/Procedure & Reference \\
\hline Crude protein & $\begin{array}{l}\text { Determination of nitrogen by using macro-KJeldahl apparatus and then multiplying it by } \\
\qquad \text { a constant of } 6.25 \text { to estimate crude protein content. }\end{array}$ & lqbal et al. 2016 \\
\hline Crude fiber & Digestion technique with $\mathrm{H}_{2} \mathrm{SO}_{4}$ and $\mathrm{NaOH}$. & Sanchez et al. 2010 \\
\hline Ether extractable fat & Extraction technique with Soxhlet apparatus. & Hakan et al. 2008 \\
\hline Total ash & Ashing of samples $\left(600^{\circ} \mathrm{C}\right)$ with a micro-muffle furnace. & Ayub et al. 2012 \\
\hline
\end{tabular}


pod formation stage of BR-99 $\left(\mathrm{C}_{2} \mathrm{~T}_{4}\right)$ yielded the maximum $(\mathrm{p} \leq 0.01)$ green forage (mean value of $20.42 \mathrm{t} \cdot \mathrm{ha}^{-1}$ for 2015 and 2016), as well as dry matter yield (mean value of $5.80 \mathrm{t} \cdot \mathrm{ha}^{-1}$ for 2015 and 2016) (Table 3), while yields for BR-90 were statistically similar when harvested at the preflowering and the complete flowering stages. BR-90 showed higher forage yields at $100 \%$ pod formation but yields were overall lower to those obtained by BR-99. The greater biomass observed for BR-99 at 100\% pod formation are likely attributable to better agronomic parameters, including plant height, stem girth, number of branches and leaf area per plant. Hakan et al. (2008) reported that due to higher genetic potential, some forage legume varieties could result in higher plant height and stem diameter, which contributed to higher cowpea green forage yields. Similarly, a greater leaf area may translate to greater light interception and overall photosynthates accumulation, resulting in greater forage yields (Mucheru et al. 2010; Motha and De 2009).

\section{Agronomic attributes and forage yield of cluster bean}

The interaction between accession ( $\mathrm{p} \leq 0.01)$ and harvesting time $(\mathrm{p} \leq 0.05)$ was significant for all agronomic variables under study, along with green forage yield and dry matter biomass (Table 2). Plant height and stem girth represent the growth of plants that contribute towards green forage yield. Cluster bean (BR-99) harvested at the $100 \%$ pod formation stage $\left(\mathrm{C}_{2} \mathrm{~T}_{4}\right)$ resulted in significantly $(\mathrm{p} \leq 0.01)$ higher plant height and stem girth, while it was statistically at par when harvested at $50 \%$ pod formation $\left(\mathrm{C}_{2} \mathrm{~T}_{3}\right)$ (Table 3$)$. The $\mathrm{BR}-90$ harvested at the pre-flowering stage $\left(\mathrm{C}_{1} \mathrm{~T}_{1}\right)$ resulted in the lowest plant height and stem girth. A linear correlation was observed between these yield components and green forage yield of cluster bean (Fig. 1), which depicted plant height and stem girth as key factors to determine and estimate green forage yield. These findings are in contradiction with

Table 2. Plant height (PH), stem girth (SG), number of branches (NB), leaf area (LA), green forage yield (GFY), dry matter yield (DMY), crude protein (CP), crude fiber (CF), ether extractable fat (EEF) and total ash (TA) of forage cluster bean accessions (BR-99 and BR-90) sown as companion crops with sorghum at different harvesting times (pre-flowering, complete flowering, $50 \%$ and $100 \%$ pod formation) under irrigated conditions at Faisalabad, Pakistan during 2015 and 2016.

\begin{tabular}{|c|c|c|c|c|c|c|c|c|c|c|}
\hline \multicolumn{11}{|c|}{ F-Values from ANOVA } \\
\hline sov & $\begin{array}{c}\text { PH } \\
(\mathrm{cm})\end{array}$ & $\begin{array}{c}\text { SG } \\
(\mathrm{cm})\end{array}$ & NB & $\underset{\left(\mathrm{cm}^{2}\right)}{\text { LA }}$ & $\begin{array}{c}\text { GFY } \\
\left(t \cdot h a^{-1}\right)\end{array}$ & $\begin{array}{c}\text { (DMY } \\
\left(t \cdot h a^{-1}\right)\end{array}$ & $\begin{array}{c}\text { CP } \\
(\%)\end{array}$ & $\begin{array}{c}\text { CF } \\
(\%)\end{array}$ & $\begin{array}{l}\text { EEF } \\
(\%)\end{array}$ & $\begin{array}{c}\text { TA } \\
(\%)\end{array}$ \\
\hline Accessions (C) & ** & * & * & $\star \star$ & $\star \star$ & $\star \star$ & * & * & * & * \\
\hline Harvesting time $(T)$ & * & * & NS & * & * & * & ** & $\star \star \star$ & * & NS \\
\hline Year $(\mathrm{Y})$ & NS & NS & NS & NS & NS & NS & NS & NS & NS & NS \\
\hline$C \times Y$ & NS & NS & NS & NS & NS & NS & NS & NS & NS & NS \\
\hline$T \times Y$ & NS & NS & NS & NS & NS & NS & NS & NS & NS & NS \\
\hline $\mathrm{C} \times \mathrm{T}$ & $\star \star$ & $\star \star$ & * & ** & $\star \star$ & * & $\star \star$ & $\star \star *$ & * & * \\
\hline$C \times T \times Y$ & NS & NS & NS & NS & NS & NS & NS & NS & NS & NS \\
\hline
\end{tabular}

${ }^{*}=$ Significant at 0.05 level, ${ }^{\star \star}=$ Significant at 0.01 level, NS = Non-significant, SOV = Source of variance.

Table 3. Plant height (PH), stem girth (SG), number of branches (NB), leaf area (LA), green forage yield (GFY), dry matter yield (DMY) of forage cluster bean accessions (BR-99 and BR-90) sown as companion crops with sorghum at different harvesting times (pre-flowering, complete flowering, $50 \%$ and $100 \%$ pod formation) under irrigated conditions at Faisalabad, Pakistan (means of 2 years data).

\begin{tabular}{|c|c|c|c|c|c|c|}
\hline Treatment & $\begin{array}{c}\text { PH } \\
(\mathrm{cm})\end{array}$ & $\begin{array}{c}\text { SG } \\
(\mathrm{cm})\end{array}$ & NB & $\begin{array}{c}\mathrm{LA} \\
\left(\mathrm{cm}^{2}\right)\end{array}$ & $\begin{array}{c}\text { GFY } \\
\left(t \cdot h a^{1}\right)\end{array}$ & $\begin{array}{c}\text { DMY } \\
\left(t \cdot h a^{1}\right)\end{array}$ \\
\hline$C_{1} T_{1}=$ Cluster bean (BR-90) harvested at pre-flowering stage & $110.50 f$ & $9.79 e$ & 24.90 & 1785.29h & $17.93 e$ & $5.04 \mathrm{e}$ \\
\hline $\mathrm{C}_{1} \mathrm{~T}_{2}=$ Cluster bean (BR-90) harvested at complete flowering & 114.61de & $10.56 \mathrm{de}$ & 24.10 & 1819.57e & $17.99 \mathrm{e}$ & $5.09 e$ \\
\hline$C_{1} T_{3}=$ Cluster bean (BR-90) harvested at $50 \%$ pod formation stage & $115.05 d$ & $10.74 \mathrm{~cd}$ & 24.33 & $1825.53 d$ & $18.45 \mathrm{~cd}$ & $5.25 c$ \\
\hline$C_{1} T_{4}=$ Cluster bean (BR-90) harvested at $100 \%$ pod formation stage & $119.15 c$ & $10.77 \mathrm{c}$ & 25.25 & $1760.21 f$ & $18.55 c$ & $5.32 b$ \\
\hline $\mathrm{C}_{2} \mathrm{~T}_{1}=$ Cluster bean (BR-99) harvested at pre-flowering stage & $112.65 \mathrm{e}$ & $10.61 d$ & 24.00 & $1780.94 \mathrm{~g}$ & $18.28 d$ & $5.11 d$ \\
\hline $\mathrm{C}_{2} \mathrm{~T}_{2}=$ Cluster bean (BR-99) harvested at complete flowering & $124.35 b$ & $10.82 b$ & 25.50 & $1829.00 c$ & $19.14 b$ & $5.28 \mathrm{~b}$ \\
\hline $\mathrm{C}_{2} \mathrm{~T}_{3}=$ Cluster bean (BR-99) harvested at $50 \%$ pod formation stage & $128.45 a b$ & $10.84 a b$ & 26.65 & $1843.56 b$ & $20.38 a$ & $5.75 \mathrm{ab}$ \\
\hline $\mathrm{C}_{2} \mathrm{~T}_{4}=$ Cluster bean (BR-99) harvested at $100 \%$ pod formation stage & $129.7 a$ & $10.97 a$ & 26.25 & $1878.68 a$ & $20.42 a$ & $5.80 a$ \\
\hline
\end{tabular}


those of Prasanthi and Venkateswaralu (2014) and Sanchez et al. (2010), who concluded that forage legumes gave the highest agronomic attributes before the initiation of pod formation, as there was a non-significant increase in plant height and stem girth on latter growth stages. However, the overall $\mathrm{N}$ demands were left unmet for cluster bean when grown as a companion crop, which resulted in reduced plant height and stem girth.

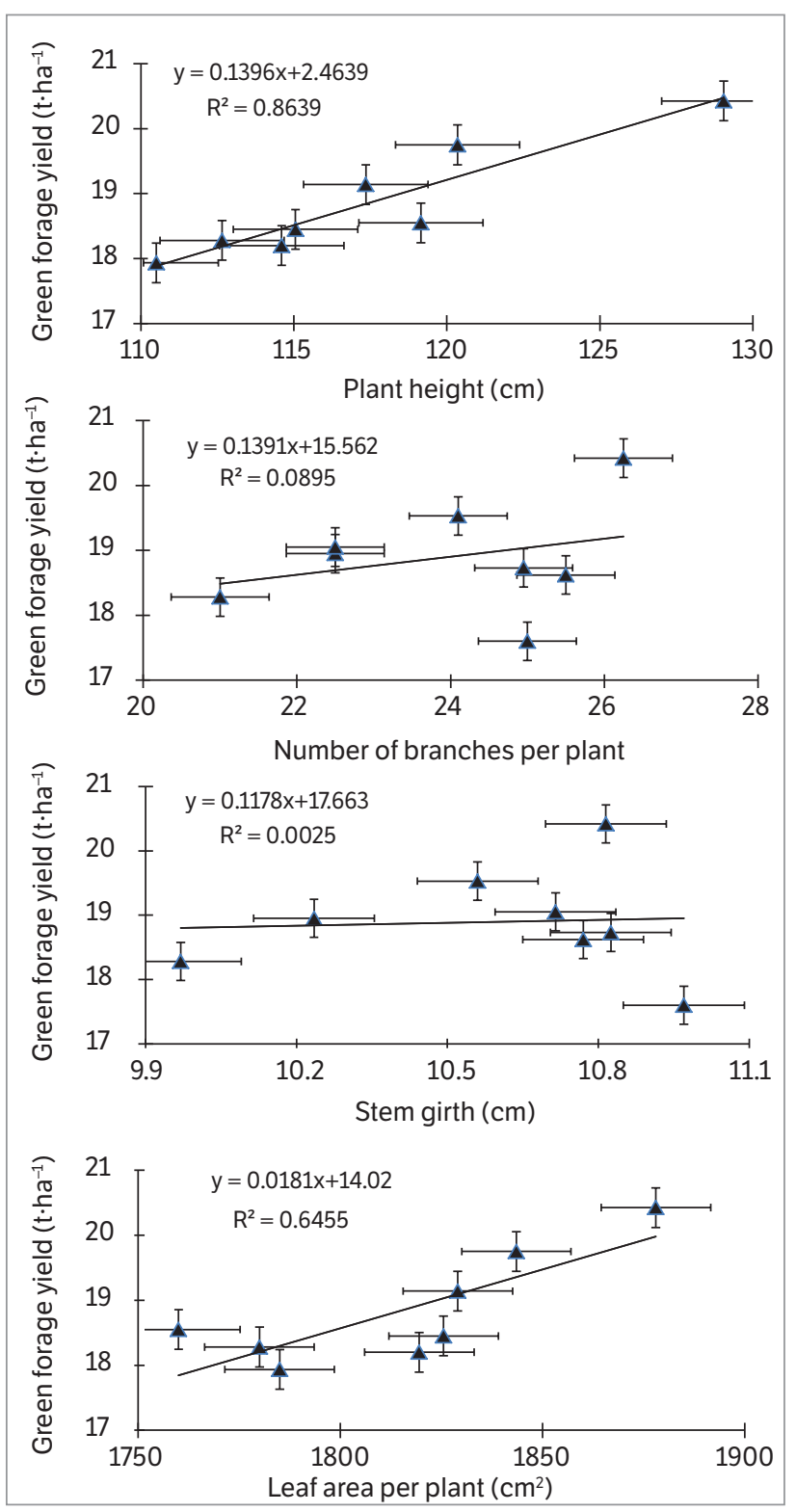

Figure 1. Pooled relationship among yield components (plant height, stem girth, number of branches and leaf area per plant), green forage yield of cluster bean accessions (BR-90 and BR-99) sown as companion crops with sorghum at different harvesting times (preflowering. complete flowering, $50 \%$ and $100 \%$ pod formation) under irrigated conditions at Faisalabad, Pakistan during 2015 and 2016 (2 years pooled data and combined analysis).
The number of branches and leaf area per plant also contribute towards final green forage yield of cluster bean. BR-99 was recorded to have statistically similar number of branches and leaf area per plant at all harvesting stages (Fig. 1). There was a trend towards higher values of number of branches and leaf area per plant at the complete flowering stage for BR-90 as compared to other harvesting stages (Table 3). The correlation analysis revealed that number of branches and leaf area per plant were linearly correlated with green forage yield of cluster bean (Fig. 1). Previously, it has been reported that cereals-cluster bean intercropping reduced the proportionate share of component crops for available nutrients, which reduced the number of branches per plant of legumes. Comparatively, fewer branches produced less number of leaves per plant, which ultimately decreased leaf area per plant in comparison with sole cropping (Agegnehu et al. 2006). Furthermore, Sawyer et al. (2010) also reported that the number of branches and leaf area of legumes were genetically controlled traits however, some of cultural practices, such as plant nutrition and harvesting time may be adjusted to further reach higher forage yields.

\section{Forage quality of cluster bean}

Cluster bean, being a rich source of plant protein, is intercropped with cereal forages, which are deficient in protein and this results in a complementary nutrient profile. Thus, there is a need to evaluate the agro-qualitative attributes of cluster bean intercropped with forage sorghum to optimize its nutritional quality. The interaction effect of accession ( $p \leq 0.05)$ and harvesting time $(p \leq 0.01)$ was significant for all agro-qualitative traits of cluster bean sown as a companion crop with forage sorghum (Table 2).

\section{Crude protein and crude fiber (\%)}

Protein is the most important quality attribute of forages, since animals have to be fed protein rich concentrates to compensate for any deficiency in animal feed. The highest ( $\mathrm{p} \leq 0.01$ ) crude protein levels (mean value of $17.95 \%$ for 2015 and 2016) of cluster bean were recorded by BR-99 harvested at $50 \%$ pod formation $\left(\mathrm{C}_{2} \mathrm{~T}_{3}\right)$, while the same intercropping system recorded the lowest $(\mathrm{p} \leq 0.01)$ crude fiber levels (mean value of $22.75 \%$ for 2015 and 2016) (Table 4). Harvesting of both accessions at $100 \%$ pod 
Table 4. Crude protein (CP), crude fiber (CF), ether extractable fat (EEF) and total ash (TA) of forage cluster bean accessions (BR-99 and BR-90) sown as companion crops with sorghum at different harvesting times (pre-flowering, complete flowering, 50\% and $100 \%$ pod formation) under irrigated conditions at Faisalabad, Pakistan (means of 2 years data).

\begin{tabular}{cccccc} 
Treatment & CP (\%) & CF (\%) & EEF (\%) & TA (\%) \\
\hline$C_{1} T_{1}=$ Cluster bean (BR-90) harvested at pre-flowering stage & $17.14 \mathrm{e}$ & $23.17 \mathrm{e}$ & $1.78 \mathrm{c}$ & $8.68 \mathrm{~d}$ \\
\hline $\mathrm{C}_{1} \mathrm{~T}_{2}=$ Cluster bean (BR-90) harvested at complete flowering & $17.46 \mathrm{c}$ & $24.38 \mathrm{~b}$ & $1.83 \mathrm{~b}$ & $8.83 \mathrm{c}$ \\
\hline $\mathrm{C}_{1} \mathrm{~T}_{3}=$ Cluster bean (BR-90) harvested at 50\% pod formation stage & $17.82 \mathrm{~b}$ & $23.44 \mathrm{~d}$ & $1.73 \mathrm{~d}$ & $8.35 \mathrm{ef}$ \\
\hline $\mathrm{C}_{1} \mathrm{~T}_{4}=$ Cluster bean (BR-90) harvested at 100\% pod formation stage & $17.05 \mathrm{f}$ & $25.25 \mathrm{a}$ & $1.72 \mathrm{~d}$ & $7.24 \mathrm{~g}$ \\
\hline $\mathrm{C}_{2} \mathrm{~T}_{1}=$ Cluster bean (BR-99) harvested at pre-flowering stage & $17.31 \mathrm{~d}$ & $23.07 \mathrm{f}$ & $1.70 \mathrm{~d}$ & $7.94 \mathrm{f}$ \\
\hline $\mathrm{C}_{2} \mathrm{~T}_{2}=$ Cluster bean (BR-99) harvested at complete flowering & $17.43 \mathrm{c}$ & $23.37 \mathrm{de}$ & $1.80 \mathrm{bc}$ & $8.51 \mathrm{e}$ \\
\hline $\mathrm{C}_{2} \mathrm{~T}_{3}=$ Cluster bean (BR-99) harvested at 50\% pod formation stage & $17.95 \mathrm{a}$ & $22.50 \mathrm{~g}$ & $1.88 \mathrm{a}$ & $9.14 \mathrm{a}$ \\
\hline $\mathrm{C}_{2} \mathrm{~T}_{4}=$ Cluster bean (BR-99) harvested at 100\% pod formation stage & $17.66 \mathrm{c}$ & $24.15 \mathrm{c}$ & $1.89 \mathrm{a}$ & $9.10 \mathrm{~b}$ \\
\hline
\end{tabular}

formation resulted in a lowering of crude protein and an increase of crude fiber content. Oseni and Aliyu (2010) and Moo (2005) also reported that forage legumes at reproductive growth stages develop more fiber, resulting in the lowering of crude protein content. It was also concluded that, at later growth stages, degradation of some proteins also caused reduction in crude protein content and, therefore, it is suggested to optimize harvesting time to improve forage nutrition.

\section{Ether extractable fat and ash (\%)}

Fats in animal feed are energy rich compounds that yield large quantities of metabolic energy after consumption. Similarly, total ash mineral constituents, such as $\mathrm{Ca}$ and $\mathrm{Mg}$, are required in numerous metabolic and tissue synthesis and repair processes. Harvesting of BR-99 at $50 \%$ pod formation $\left(\mathrm{C}_{2} \mathrm{~T}_{3}\right)$ resulted in the highest ( $p \leq 0.05$ ) ether extractable fat (mean value of $1.88 \%$ for 2015 and 2016) and total ash content (mean value of 9.14\% for 2015 and 2016) (Table 4). At earlier harvesting times (pre-flowering and complete flowering) as well as at $100 \%$ pod formation, both accessions had lower ether extractable fats as well as total ash contents. Similar to our findings, Ghosh (2004) also reported that cereal-legume intercropping was instrumental in decreasing fat and ash contents of forage legumes owing to sub-optimal plant nutrition. However, it was suggested that harvesting time of companion crops was crucial in determining the forage quality and the recommendation was to harvest forage after the flowering stage for obtaining high quality forage.

\section{Economic analysis and benefit-cost ratio}

All agricultural activities revolve around economics, as is the case for forage production. Different accessions of cluster bean sown as companion crops with forage sorghum resulted in differential gross monetary benefit and net monetary benefits. However, cluster bean (BR-99) harvested at $100 \%$ pod formation resulted in the highest net income (Table 5), being closely followed by same accession harvested at $50 \%$ pod formation. The same trend was recorded for the benefit to cost ratio of cluster bean based intercropping systems. The obvious reason behind higher economic returns and benefit to cost ratio rendered by BR- 99 harvested at $50 \%$ pod formation was a higher biomass production, with relatively smaller extra investment. In agreement with our findings, Dapaah et al. (2003) and Banik et al. (2000) reported that companion crops harvested at different intervals affect forage yield and, ultimately, economic returns. However, it was suggested that the effect of harvesting time was more pronounced for forage quality in comparison with forage yield and economic returns.

The research findings suggest an appropriate harvesting stage for obtaining quality forage under intercropping systems, which could go a long way in the improvement of animal nutrition status and, ultimately, food security of subsistence farmers. However, there is a dire need to develop and evaluate high yielding accessions to optimize their harvesting time under varied agro-ecological and agroenvironmental conditions. Furthermore, altering the sowing time rather than harvesting time of companion crops under intercropping systems may also be evaluated as a potential 
Table 5. Economic analysis and benefit to cost ratio (BCR) of forage cluster bean accessions (BR-90 and BR-99) sown as companion crops with sorghum at different harvesting times (pre-flowering, complete flowering, $50 \%$ and $100 \%$ pod formation) under irrigated conditions at Faisalabad, Pakistan during 2015 and 2016 ( 2 years pooled data and combined analysis).

\begin{tabular}{|c|c|c|c|c|}
\hline Treatments & $\begin{array}{c}\text { Total Expenditures } \\
\text { (fixed+variable) (US\$ ha } \mathbf{a}^{-1} \text { ) }\end{array}$ & $\begin{array}{l}\text { Gross Income } \\
\text { (US\$ ha-1) }\end{array}$ & $\begin{array}{l}\text { Net Income } \\
\text { (US\$ ha') }\end{array}$ & BCR \\
\hline $\mathrm{C}_{1} \mathrm{~T}_{1}=$ Cluster bean (BR-90) harvested at pre-flowering stage & $137.25+22.00=157.25$ & 537.90 & 380.65 & 3.42 \\
\hline $\mathrm{C}_{1} \mathrm{~T}_{2}=$ Cluster bean (BR-90) harvested at complete flowering & $137.25+22.00=157.25$ & 546.00 & 388.75 & 3.47 \\
\hline $\mathrm{C}_{1} \mathrm{~T}_{3}=$ Cluster bean (BR-90) harvested at $50 \%$ pod formation stage & $137.25+22.00=157.25$ & 553.50 & 396.25 & 3.51 \\
\hline $\mathrm{C}_{1} \mathrm{~T}_{4}=$ Cluster bean (BR-90) harvested at $100 \%$ pod formation stage & $137.25+22.00=157.25$ & 556.50 & 399.25 & 3.53 \\
\hline$C_{2} T_{1}=$ Cluster bean (BR-99) harvested at pre-flowering stage & $137.25+25.00=162.25$ & 548.40 & 386.15 & 3.37 \\
\hline $\mathrm{C}_{2} \mathrm{~T}_{2}=$ Cluster bean (BR-99) harvested at complete flowering & $137.25+25.00=162.25$ & 574.20 & 411.95 & 3.53 \\
\hline$C_{2} T_{3}=$ Cluster bean (BR-99) harvested at $50 \%$ pod formation stage & $137.25+25.00=162.25$ & 592.50 & 430.25 & 3.65 \\
\hline $\mathrm{C}_{2} \mathrm{~T}_{4}=$ Cluster bean (BR-99) harvested at $100 \%$ pod formation stage & $137.25+25.00=162.25$ & 600.70 & 438.45 & 3.70 \\
\hline
\end{tabular}

Gross income $=$ forage yield $\left(t \cdot h a^{-1}\right) \cdot$ US\$ 30 ton $^{-1}$ (market rate of forage).

alternative management practice for boosting biomass production with improved agro-qualitative attributes.

\section{CONCLUSION}

We had hypothesized that harvesting time of forage cluster bean accessions sown as companion crops with forage sorghum would increase the yield of cluster been. It was furthermore hypothesized that forage quality and economic returns could also be increased by optimizing harvesting time. The results revealed that the BR-99 accession had greater yields when intercropped with forage sorghum. It also had higher quality forage and significantly greater economic returns when harvested at $50 \%$ pod formation. Forage quality was especially suboptimal at the pre-flowering and complete flowering stages, while it peaked at the 50\% pod formation and then again deteriorated at the $100 \%$ pod formation. Thus, it is suggested to harvest companion crops of cluster bean at the $50 \%$ pod formation stage, instead of the pre-flowering and complete flowering stages.

\section{ACKNOWLEDGEMENTS}

The study was funded by the Higher Education Commission (HEC) of Pakistan under the Indigenous Fellowship Scheme (5k-Fellowships Pin\# 2AV1-215).

\section{ORCID ID}

\author{
M. A. Iqbal \\ iD http://orcid.org/0000-0003-2701-0551
}

\section{REFERENCES}

Agegnehu, G., Ghizaw, A. and Sinebo, W. (2006). Yield performance and land-use efficiency of barley and faba bean mixed cropping in Ethiopian highlands. European Journal of Agronomy, 25, 202-207. http://dx.doi.org/10.1016/j.eja.2006.05.002.

Ahmad, A. H., Ahmad, R., Ahmad, N. and Tanveer, A. (2007). Performance of forage sorghum intercropped with forage legumes under different planting patterns. Pakistan Journal of Botany, 39, 431-439.

Alshameri, A., Fahad, A. Q., Salim, K., Mohammad, N., Abdel-Rhman, G., Mohamed, T., Abdulhafed, A., Saleh, A. and Muhammad, A. (2017). Appraisal of guar (Cyamopsis tetragonoloba Taub) accessions for forage purpose under the typical Saudi Arabian environmental conditions encompassing high temperature and drought. Pakistan Journal of Botany, 49, 1405-1413.

Allen, V. G., Baker, M. T., Segarra, E. and Brown, C.P. (2007). Integrated irrigated crop livestock systems in dry climates. Agronomy Journal, 99, 346-360. http://dx.doi.org/10.2134/agronj2006.0148.

Ayub, M., Nadeem, M. A., Naeem, M., Tariq, M. and Ahmad, W. (2012). Effect of different levels of $P$ and $K$ on growth, forage yield and quality of cluster bean (Cyamopsis tetragonolobus L.). The Journal of Animal and Plants Sciences, 22, 479-483. 
Ayub, M., Khalid, M., Tariq, M., Nadeem, M. A. and Naeem, M. (2011). Effect of different seeding densities and nitrogen levels on growth, forage yield and quality attributes of Cluster bean (Cyamoposis tetragonoloba Tuab.). Journal of Agricultural Technology, 7, 1409-1416.

Ayub, M., Tahir, M., Nadeem, M. A., Zubair, M. A., Tariq, M. and Ibrahim, M. (2010). Effect of nitrogen applications on growth, forage yield and quality of three cluster bean varieties. Pakistan Journal of life \& Social Sciences, 8, 111-116.

Ayub, M. and Shoaib, M. (2009). Studies on fodder yield and quality of sorghum grown alone and in mixture with guara under different planting techniques. Pakistan Journal of Agricultural Sciences, 46, 25-29.

Banik, P., Samsal, T., Ghosal, P. K. and Bagchi, D. K. (2000). Evaluation of mustard (Brassica compestris var toria) and legume intercropping under 1:1 and 1:2 row replacement series system. Journal of Agronomy and Crop Science, 185, 9-14. http://dx.doi. org/10.1046/j.1439-037X.2000.00388.x.

CIMMYT. (1988). An economic training handbook. Economic programme, CIMMYT. Mexico.

Dapaah, H. K., Asafu-Agyei, J. N., Ennin, S. A. and Yamoah, C. (2003). Yield stability of cassava, maize, soya bean and cowpea intercrops. Journal of Agricultural Sciences 140, 73-80. http:// dx.doi.org/10.1017/S0021859602002770.

Ghanbari, B. A. and Lee, H. C. (2003). Intercropped wheat (Triticum aestivum L.) and bean (Vicic faba L.) as a whole crop forage: Effect of harvest time on forage yield and quality. Grass \& Forage Science, 27, 535-539. http://dx.doi.org/10.1046/j.1365-2494.2003.00348.x.

Ghosh, P. K., Tripathi, A. K., Bandyopadhyay, K. K. and Manna, M. C. (2009). Assessment of nutrient competition and nutrient requirement in soybean/sorghum intercropping system. European Journal of Agronomy, 31, 43-50. http://dx.doi.org/10.1016/j.eja.2009.03.002.

Ghosh, P. K. (2004). Growth, yield, competition and economics of groundnut/cereal fodder intercropping systems in the semi-arid tropics of India. Field Crops Research, 88, 227-237. https://doi. org/10.1016/j.fcr.2004.01.015.

Hakan, G., Avcioglu, R., Soya, H. and Kir, B. (2008). Intercropping of corn with cowpea and bean: Biomass yield and silage quality. African Journal of Biotechnology, 22, 4100-4104.

Iqbal, M. A. (2015). Cluster bean (Cyamopsis tetragonoloba L.) germination and seedling growth as influenced by seed invigoration techniques. American-Eurasian Journal of Agricultural \& Environmental Sciences, 15, 197-204. https://doi.org/10.5829/ idosi.aejaes.2015.15.2.12506.

Iqbal, M. A. and lqbal, A. (2015). Overviewing forage shortage for dairy animals and suitability of forage sorghum for ensiling. Global Veterinaria, 14, 173-177. https://doi.org/10.5829/idosi. gv.2015.14.02.92128.

Iqbal, M. A., Iqbal, A., Akbar, N., Khan, H. Z. and Abbas, R. N. (2015). A study on feed stuffs role in enhancing the productivity of milch animals in Pakistan- Existing scenario and future prospect. Global Veterinaria, 14, 23-33. https://doi.org/10.5829/idosi. gv.2015.14.01.91188.

Iqbal, M. A., Iqbal, A., Ayub, M. and Akhtar, J. (2016). Comparative study on temporal and spatial complementarity and profitability of forage sorghum-soybean intercropping systems. Custos e Agronegocio online, 12, 2-18.

Iqbal, M. A., Bethune, B. J., Asif, I., Rana, N. A., Zubair, A., Haroon, Z. K. and Bilal, A. (2017). Agro-botanical response of forage sorghumsoybean intercropping systems under atypical spatio-temporal pattern. Pakistan Journal of Botany, 49, 987-994.

Iqbal, M. A., Muzammil, H. S., Sher, A., Zahoor, A., Qaiser, M. and Rana, D. K. (2018a). Forage productivity of cowpea [Vigna unguiculata (L.) Walp] cultivars improves by optimization of spatial arrangements. Revista Mexicana de Ciencias Pecuarias, 9, 203219. http://dx.doi.org/10.22319/rmcp.v9i2.4335.

Iqbal, M. A., Asif, I. and Rana, N. A. (2018b). Spatio-temporal reconciliation to lessen losses in yield and quality of forage soybean (Glycine max L.) in soybean-sorghum intercropping systems. Bragantia, 77,283-291. http://dx.doi.org/10.1590/1678-4499.2017043.

Lesoing, G. W. and Francis, C. A. (1999). Strip intercropping effects on yield and yield components of corn, grain sorghum, and soybean. Agronomy Journal, 91, 807-813. https://doi.org/10.2134/ agronj1999.915807x.

Moo, S. L. (2005). Effect of inter-cropping on the growth characteristics, yield and palatability of sorghum $x$ sudangrass hybrid in 1st, 2nd and 3rd cutting time. Journal of Korean Society of Grassland \& Forage Sciences, 25, 23-32. http://dx.doi.org/10.5333/ KGFS.2005.25.1.023.

Motha, N. K. and De, R. (2009). Intercropping maize and soybean. Journal of Agricultural Science, 95, 117-122. 
Mucheru, M. M., Pypers, P., Mugendi, D., Kungu, J., Mugwe, J., Merckx, R. and Vanlauwe, B. (2010). A staggered maize-legume intercrop arrangement robustly increases crop yields and economic returns in the highlands of Central Kenya. Field Crops Research, 115, 132-139. http://dx.doi.org/10.1016/j.fcr.2009.10.013.

Oseni, T. O. and Aliyu, I. G. (2010). Effect of row arrangements on sorghum-cowpea intercrops in the semi-arid savannah of Nigeria. International Journal of Agriculture and Biology, 12, 137-140.

Prasanthi, K. and Venkateswaralu, B. (2014). Fodder quality in fodder maize-legume intercropping systems. Journal of Tropical Agriculture, 52, 86-94.
Sanchez, D. G. R., Silva, J. T. E., Gil, A. P., Corona, J. S. S., Wong, J. A. C. and Mascorro, A. G. (2010). Forage yield and quality of intercropped corn and soybean in narrow strips. Spanish Journal of Agricultural Research, 8, 713-721. http://dx.doi.org/10.5424/ sjar/2010083-1269.

Sawyer, J. E., Pedersen, P., Barker, D. W., Diaz, D. A. R. and Albrecht, L. (2010). Intercropping corn and kura clover: response to nitrogen fertilization. Agronomy Journal, 102, 568-574. http://dx.doi. org/10.2134/agronj2009.0392.

Zerbini, E. and Thomas, D. (2003). Opportunities for improvement of nutritive value in sorghum and pearl millet residues in South Asia through genetic enhancement. Field Crop Research, 84, 10-15. https://dx.doi.org/10.1016/S0378-4290(03)00137-0. 